\title{
Obituary
}

\section{An Academic Obituary of Eric McLuhan}

\author{
Robert K. Logan \\ Department of Physics, University of Toronto, 60 St. George, Toronto, ON M5S 1A7, Canada; \\ logan@physics.utoronto.ca
}

Received: 12 June 2018; Accepted: 12 June 2018; Published: 13 June 2018

B.Sc.-Communications, Wisconsin State University, 1972

M.A., Ph.D.-English Lit., University of Dallas, 1980, 1982

Eric McLuhan, a Canadian scholar, public intellectual and a much sought-after speaker, was born on 19 January 1942 and passed away on 18 May 2018 in Bogota, Columbia, the day after he gave a commencement address at the Universidad de la Sabana. A funeral was held in Bogata on 19 May and a memorial mass was held at St. Gregory the Great, Roman Catholic Church, Picton, Ontario on 25 May.

Eric will be deeply missed by his wife Sabina, and his three children Emily, Anna and Andrew. He will also be missed by the entire media ecology community that was inspired by his deep insights into the effects of media. Eric was a prolific writer having written 18 books and over 100 articles. He was a close collaborator of (his father) Marshall McLuhan.

His accomplishments as a scholar were manifold, but here I concentrate on four of them:

- First, there was the collaboration with his father including his co-authorship with Marshall McLuhan and Kathryn Hutchon (later Kawasaki) of City as Classroom.

- Secondly, there was the way he rescued the work of his father after Marshall's passing in 1980. He did this by mining the archives of his father's papers and co-authoring with his father (posthumously) the following four books:

- Laws of Media: The New Science

- $\quad$ The Lost Tetrads of Marshall McLuhan

- Media and Formal Cause

- Theories of Communication.

I believe that without Eric's contribution to the first two books published after his father's death that the laws of media (LOM) tool, that is so essential to the study of media ecology today, would not have become part of the canon of this field. The importance of the third book is that, as a result of its publication, the prominence of formal cause in the field of media ecology has been secured and is actively discussed. The fourth book provides the historic arc of communication theories including Marshall McLuhan's own description of his theory of communication.

- A third key contribution to the field of media ecology is that Eric actually coined the term 'media ecology' by which the field, started by his father, came to be known by. He did this while visiting Fordham University in New York City with his father in 1967. The term was picked up shortly thereafter by Neil Postman, who started the media ecology program at New York University. The term was also incorporated in the title of the Media Ecology Association in which Eric was very active, often as a key note speaker.

- Finally, the fourth key contribution of Eric's were the many new areas of study that he opened up on his own with his publication of the following books that he authored, co-authored or edited: 
- The Sensus Communis-Synesthesia, and the Soul (a study of common sense, the five bodily senses and mimesis),

- Cynic Satire (a study of Menippean satire),

- The Human Equation (a series of five books co-authored with Wayne Constantineau that deals with body's role in perception and understanding),

- The Role of Thunder in Finnegan's Wake (an analysis of the ten thunder words in James Joyce's Finnegan's Wake),

- Electric Language: Understanding the Present, (an analysis of how digital media of the personal computer, the tablet, and the Internet are changing the nature of communications as well as spoken and written language,

- Essential McLuhan, edited with F. Zingrone (a collection of the writings of Marshall McLuhan),

- Who Was Marshall McLuhan? edited with F. Zingrone and W. Constantineau (a collection of the impressions of people who knew and/or worked with Marshall McLuhan including yours truly),

- The Medium and the Light: Writings on Religion by Marshall McLuhan, edited with Jacek Schlarek (a collection of the religious writings and reflections of Marshall McLuhan),

- The Book of Probes edited with W. Kuhns (a collection of Marshall McLuhan's one-liners),

- McLuhan Unbound edited with Terrence Gordon (a collection of 20 essays by Marshall McLuhan).

Allow me to end this obituary with a personal note: I will miss Eric, a true friend, who was a very special person, always of good cheer, generous and kind who lived his faith-respectfully and reverently. 